\title{
Studying the Place of Intertextuality in Iranian Painting (Case Samples: Qajar Era)
}

\author{
Panahi Siamak $^{1}$, Farazjou Forough ${ }^{2} \&$ Majdi Shima $^{3}$ \\ ${ }^{1} \mathrm{Ph}$. D. of Architecture, architecture faculty, Islamic Azad University, Abhar branch, Abhar, Iran \\ ${ }^{2}$ Ph. D. of Architecture, architecture faculty, Islamic Azad University, Khoy branch (Ghareh Ziaeddin), Khoy, \\ Iran \\ ${ }^{3}$ Ph. D. of Architecture, architecture faculty, Islamic Azad University, Ramsar branch, Ramsar, Iran \\ Correspondence: Dr Panahi Siamak, Ph. D. of Architecture, architecture faculty, Islamic Azad University, Abhar \\ branch, Abhar, Iran. E-mail: siamak_architecture@yahoo.com
}

Received: June 15, 2016

doi:10.5539/mas.v10n12p156
Accepted: July 1, $2016 \quad$ Online Published: August 15, 2016

URL: http://dx.doi.org/10.5539/mas.v10n12p156

\begin{abstract}
Intertextuality studies are as one of the significant approaches in literature and art. This term for the first time was proposed by Julia Kristeva 60s and later it was expanded by persons such as Roland Barthes, Gerard Genette $\&$ et al. Nowadays we are living in a world which is full of texts and these texts are born in it, grow and finally give their place to other texts but they aren't disappeared. These texts are knotted to each other with intertextuality rules and they have interaction with each other. They sometimes deny or confirm each other but any way they influence on each other. In fact existence of sign world and existing texts and their effects in creation of each artistic effect are inevitable.

This paper intends to consider the applicable studies of intertextuality in Iranian community art by concentrating on Qajar era painting. And it refers to the role of intertextuality in producing and reading the works by studying the case samples.

The methodology in this research with review of art history and due to the analyses done on the works (sample to sample) will be analytic-descriptive according to the allegorical method.
\end{abstract}

Keywords: intertextuality, sign, text, Qajar painting, Iranian art

\section{Introduction}

Intertextuality reminds this point that all texts in potential, pluralistic and returnable form are exposed to the special presumption of reader without clear and defined borders and always involved in expression or suppression of conversation tones existing in the community. Intertextuality as a term that constantly refers to the lack of oneness, unity and therefore indisputable power is still a powerful tool in the theoretical words circle of each reader (Allen, 2006, p. 297).

In intertextuality studies, two points should be considered, first this issue that adherence and the relation between the texts or intertextuality can be studied in two longitudinal (in time) and horizontal (simultaneity) domains. In other words, human utilizes of both previous and contemporary texts, second, referring to the past texts is sometimes receivable obviously and explicitly, but sometimes this referring has been in non-explicit form and for recognition of borrowed element, we need to be more precise and think more. Another important point is that the researchers often know the intertextuality limited to the literal issues while this study in different domains of art like cinema, theatre, music, painting and etc is also thinkable.

Intertextuality studies in this research have three features: firstly, it is a practical and applicable sample; secondly the study body is from Iranian culture; thirdly this cultural body is from Iranian art domain.

\section{Theoretical Approach}

\subsection{Intertextuality Quiddity}

\subsubsection{Studying the Views and Theories}

Trans Hax says each sign acts and finds meaning in relation with other signs. Allen relates Saussure theory about 
«language system» to the «literal system» and says the literal authors seek color, species features, personification dimensions, mental forms, narrative methods and even phrases and sentences in their texts and literature tradition (Allen, 2006). Through this way, they connect their literal texts to the texts before themselves and their meaning is perceivable in relation with these mass references.

In Allen's belief, «literal works are established according to the systems, codes and traditions created in previous literal works. Other systems, codes and artistic and generally cultural traditions have significant importance in formation of the meaning of a literal work. Today's theorists know the texts whether literal or non-literal without any kind of independent meaning (Allen, 2006), because the texts have been formed from a thing which is called intertextuality.

\subsection{Application of Intertextuality in Art}

By studying the applicability of intertextuality domain by the persons like Laurent Gennie and Michael Riffaterre, the intertextuality studies about art also enter to a new stage and intertextuality is also used for criticizing the artistic works.

Culturally, the relations between two texts can have two general states:

Both of them belong to a special culture and the intertextuality is inter-cultural. The intertextuality relations in this case are connected to two species:

Intra-sign: both works belong to a same sign system. For example both of them are verbal or figurative,

And inter-sign: when both works belong to two different systems, for example a film which has been adapted from a same novel (Namvar, 2011, p. 319).

\subsection{Comparative Study of Works}

Existence of common elements necessitates the comparative study. It is necessary to be reminded that existence of similarities and relation between two works isn't a new issue. What can be new in this paper aside from the manner of comparative study of these two figures is more related to the interpretation which will be obtained at the end of such comparison. In comparative study, it is tried that similarities and differences of these two texts to be studied respectively and according to the clear and evident documents and reasons, the relation between intended works is indicated. This issue that the relation has been direct or it has been accomplished with intermediator figure is in turn another issue. But finally their relation and proportion can be proved and their excessive common aspects can not be due to be random (Namvar, 2011, p. 304).

\subsection{The Role of Sign World}

Most of artistic and literal works and even those which have been assumed historical and documentary are formed in a sign process in textual world. Sign world acts very mysteriously and creepily and identification of relational strings sometimes becomes different or even impossible. These works are sometimes readable and due to this issue that the related texts have been disappeared, they are not sometimes readable in intertextual and sign form.

\subsection{Mutual Referral and Dual Implication}

Referral is in two forms: first, historical referral through mimesis or imitation and second intertextual referral through semiology or semiotics, these two species of referral cause a work to exit from an explicit and one-layer text and then it is converted to an implicit and multi-layer text. In other words, the issue isn't only historical quotation or historical event, rather this is the first level of reading namely imitating (mimesis) of figure. Second level of reading considers the implicit implications of the figure and passes from implicit implications. In this level, intertextual relations indicate themselves and reading of figure is accomplished in the sign world. Such a reading can be decoded by using of previous texts (Namvar, 2011, p. 286).

The primary text which is the main reason of creation of work is called the first implication namely signification and the second implication is called significance. A reading which suffices to a meaning is signification, such a reading is one dimensional and one-meaning. In the second reading namely significance, the meaning isn't static and the same referent, rather in addition to the signification which exists in the first level of reading, meaning also has fluidity and it is coming and going between different referents. Referent is sometimes evident and sometimes non-evident. The second level of reading also has other codes and the first level isn't encoded simply (adapted from Namvar, 2011).

Sign system has more freedom and it trains the possibility of creativity in itself. It is unlike the mimesis system that faithfulness is considered like imitation exactly and creativity is considered like unfaithfulness. Therefore, 
the sign system with creativity and innovation can have deeper effectiveness and it will have more capability for convincing and influencing (Namvar, 2011, p. 354).

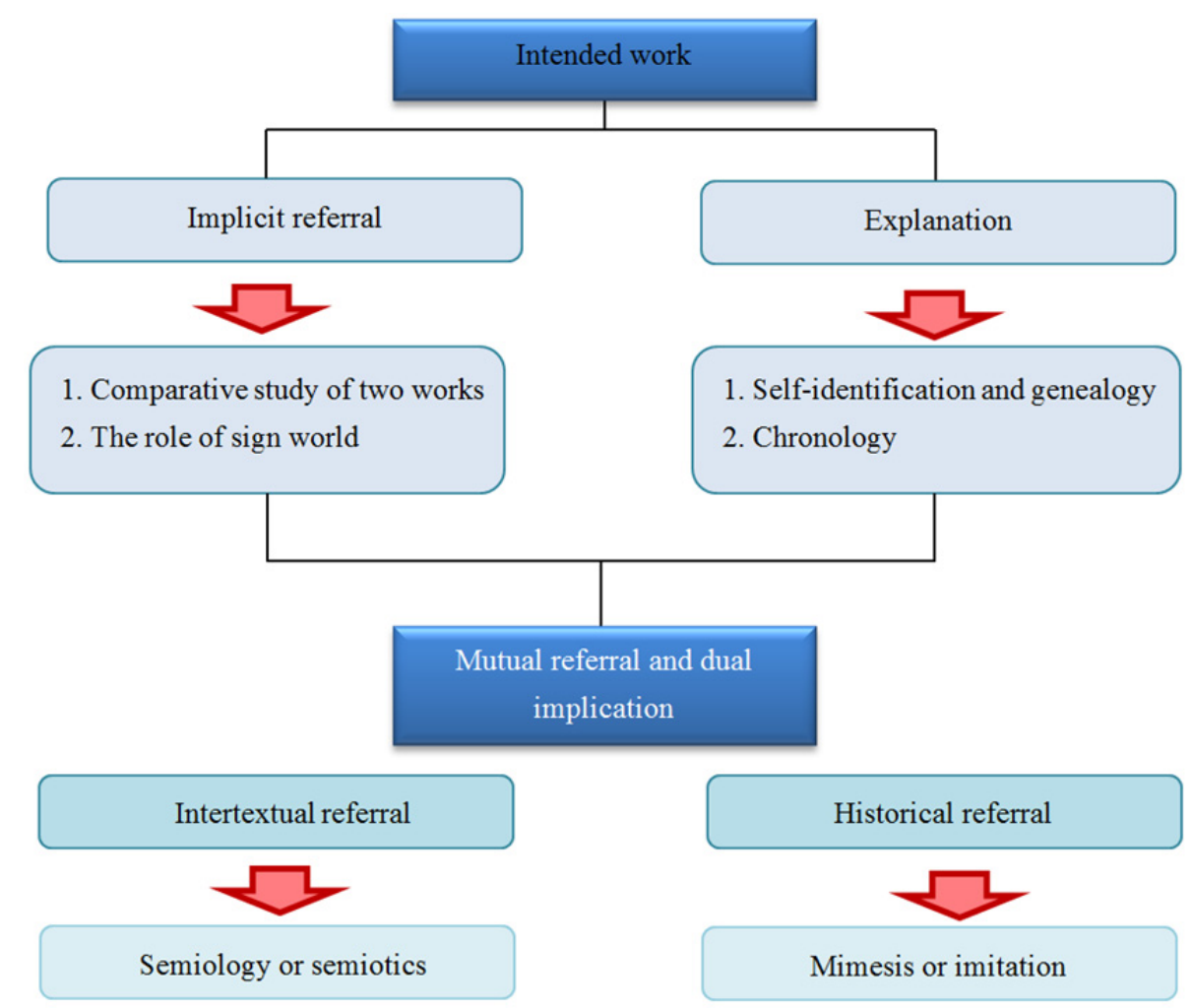

Figure 1. The referral mutuality model in a work according to the view of Dr. Namvar Motlagh, Bahman (reference: authors)

\section{Discussion and Study}

\subsection{Qajar Era Painting}

Qajar era art is somehow a boundary between Iran's traditional art and modern art and in fact it is considered as the passage period of Iran's art from its noble and traditional forms to its new forms and modern tendencies. In $13^{\text {th }}$ century, a real regeneracy took place; Qajar hierarchy provided the possibility for creative persons to be grown again; in this era, art was entering to its new era. Qajar painting art can be divided into two general periods:

Table 1. Division of Qajar painting art (reference: authors)

\begin{tabular}{|c|c|}
\hline First period & eriod \\
\hline eriod of Fath Ali Shah Qajar kingdom & Ird \\
\hline $\begin{array}{l}\text { Its } \mathrm{sp} \\
\text { expres }\end{array}$ & 1ctory to \\
\hline $\begin{array}{l}\text { last achievement of artists a } \\
\text { values in Iran. }\end{array}$ & $\begin{array}{l}\text { stern countries with entering the } \\
\text { ind king's travels and photography }\end{array}$ \\
\hline $\begin{array}{l}\text { It was a proper opportunity so that famous painters } \\
\text { about him to amend the current method and } \\
\text { immediately prior to their era namely Zandieh } \\
\text { school. }\end{array}$ & $\begin{array}{l}\text { The presence of new facilities like lithography and } \\
\text { progress of the artistic culture level of people underlie to } \\
\text { create people or public artistic movement called coffee } \\
\text { house painting }\end{array}$ \\
\hline
\end{tabular}

In referring to the paintings of $12^{\text {th }}$ century in perception of texts and lower layers, we face with elegant points: 
Table 2. Features of Qajar painting art (reference: authors)

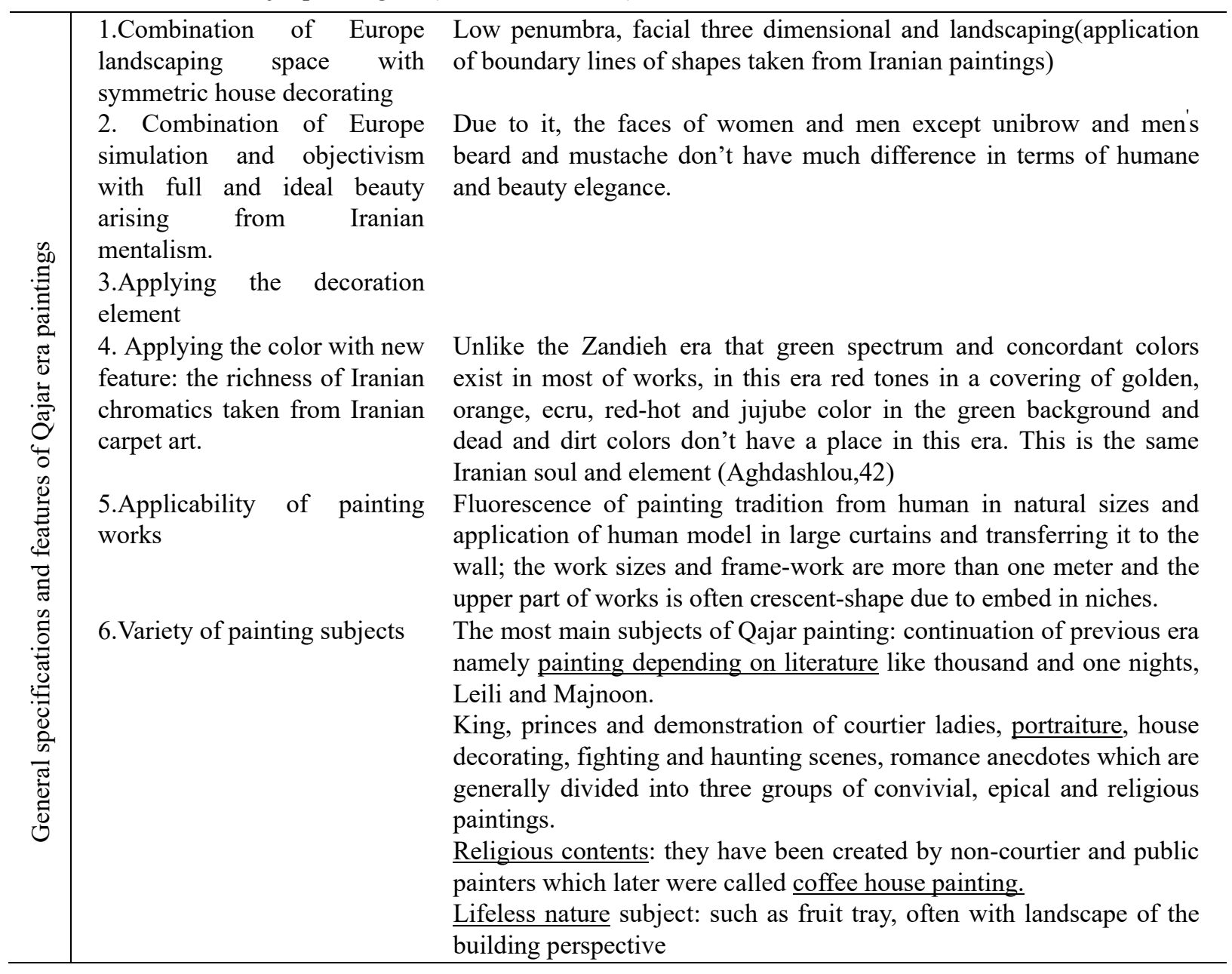

During 50-year period of Nasereddin Shah, the factors such as development of printing industry, establishment of Dar ul-funun, creation of army and new system, genesis of newspaper, connection with western culture and translation of European literal and scientific texts, genesis of photography (more and quicker than painting) have indicated daily life of people in that time and their effects are evident in painting art.

\subsubsection{Studying the Painting and Depiction in Qajar Era}

Table 3. Division of Qajar painting art (reference: authors)

\begin{tabular}{llll}
\hline \multicolumn{6}{l}{ Totally in this era, painting and depiction grew in three parts } \\
\hline $\begin{array}{l}\text { Paintings and curtains } \\
\text { with portraiture }\end{array}$ & $\begin{array}{l}\text { Landscaping and lifeless nature which were } \\
\text { enforced with water-color and oil-color and } \\
\text { subjects }\end{array}$ & generally they have been related to the court & $\begin{array}{l}\text { paintings that we call them coffee } \\
\text { house painting. }\end{array}$ \\
\hline
\end{tabular}

\subsection{Qajar Era Painters and Studying the Effects and Signs Hidden in Them}

In a general division in terms of the attitude kind and artistic performance, perhaps the artists of $13^{\text {th }}$ century can be included in three groups:

1) First, artists of Fathalishah court that includes artists such as: Mirzababa, Esfahani, Mehr Ali and Abdollahkhan.

2) Second, pioneer artists that created new space in Iran painting by keeping ideal look of Iranian painter and approach to a world which is renewing, such as Mirza Abolhassan khan Ghaffari (saniolmolk), Mahmoudkhan saba (Malekolshoara), Esmaielkhan Jalayer. 
3) Third, artists that often attempted to replace the objective worldview instead of traditional image culture (an Iran that has root in the hallucination world), like: Ghaffari, Mohammad (Kamalolmolk) and Aslafesh (Hosseini, 2003).

\subsubsection{First Period}

Mirzababa Naghashbashi: he has been from famous oil-color painters in Zandieh and Fathalishah era and he has been the Naghash Bashi of Fath Ali Shah era that has skill in different methods. He was precise and elegant in simulation and portraiture and applied the colors symmetrically and concordantly. He applied special frames in designing the flowers and other decorations of fabrics and used of frame for regular and equal decoration in the whole of the garment surface with flower.

Mehr Ali Naghash Bashi: he was the portraitist and simulator of Fath Ali Shah era and simulated from king more. $\mathrm{He}$ tried to simulate the face and he was precise in presenting the states and decoration of garments. And in demonstration of glory and power of king, he applied his utmost. The main part of his skill was in the oil-color method but he had skill in oil binding (pen-case), water-color and paintings behind glass. He signed his works with Nasta'liq handwriting and mentioned the enforcement date under his works and with inserting the sentences of the least servant knew himself as servant that has born in king's house and he has had the position of court's Naghash Bashi after Mirzababa, but due to his respect on that position, he has disregarded Naghash Bashi title.

In studying this work, we consider two specified works of two French painters called Jerard, Fransis (1770-1837) and Lefevre Robert (175-1830). Because these two artists with regard to the historical section and their activity domain have a work that in terms of combination, subject, work technic and symbols presented in the work are similar not only with each other but also with two drawn figures of Mehr Ali Mirza in Iran that indicates cultural-artistic interactions and its effect on painting art Qajar era. An era that neoclassic has ebbed and coincident with the middle of Qajar era in Iran namely when Iran has passed first war with Russia and second war is inevitable. In this era, two works of one of the court's artists with regard to be similar with the works of Jerard and Lefevre have special importance.

Studying the details and similarities of these five works which have taken place during 10 years confirms this issue that Qajar painters have had awareness of the works of their contemporary artists in France and they have taken model from them and they have had necessary information of the procedure of names which have been the basis of creation of such works. As neoclassic works of Europe especially France relies on the art principles of Rome and Greece art. Also in Iran, we observe the reliance on the art of ancient age in creation of works, a thing which has been considered less in previous periods and with reduction of decorations in neoclassic, in the painting of this period, the elimination of miniature elaborate works of previous periods is also evident. Deep plans with effectiveness of light and contents of real figure of human according to the ancient cultural-artistic nobleness are from the most important elements which are seen in this period and this issue indicates a performance parallel to Europe neoclassic in Iran of that period. This performance has been mixed with a factor called religion and it has led to create new creativities with Iranian nobleness and quality.

Architecture Abdollahkhan Naghash Bashi: prestigious architecture and painter of $13^{\text {th }}$ century had high rank in Fath Ali Shah and Mohammad Shah era and early part of Nasereddin Shah Kingdom. According to the saying of Sir William Foster, he has had the title of Naghash Bashi in Fath Ali Shah court.

\subsubsection{Second Period}

Mirza Abdolhassan Khan Ghaffari (Saniolmolk): About 1842 and at the time of Mohammad Shah kingdom that has been a 29-year old young king, has made a good color-oil tableau and due to present it, he has become one of the courts painters. He was from the generation of Ghaffari Kashani painters and he is in the category of first artists that was sent to Europe for studying the painting. And in 1861 according to the command of Nasereddin Shah, the right of print and publication of newspaper was given to him and it was published up to No.471. After receiving the title of Saniolmolk and due to this issue that he was interested in establishment of painting conservatory, formally endeavored for opening the painting conservatory. His conservatory was called Majma al Sanaye or Majma dar alsanaye. His works indicate the social and political conditions of his time.

Mahmoudkhan Saba (Malekolshoara): he studied in the field of the sciences (in Nasereddinshah time) and acquisition of knowledge and art in the literature, mathematics, mysticism and history. He has the position of Malekolshoara in Neserddin shah court but he can be accounted as one of the unique painters of Naseri that has had special style and method in Iranian painting.

\subsubsection{Third Period}

Ghaffari, Mohammad (Kamal-ol-molk): the most famous painter of Ghaffari family is from Kashan and he is 
known as Kamal-ol-molk. His teacher in Dar ul-Funun was Mozayenoddoleh. In 1884 due to his constant and skillful attempts, he was known as Naghash Bashi of imperial presence. The work of the Hall of Mirror is the memorial of these same years and it is the first and only work of Nasereddin Shah era that inserted its Kamal-ol-molk title in it.

Table 4. Studying the paintings of first period of Qajar according to intertextually (reference: authors)

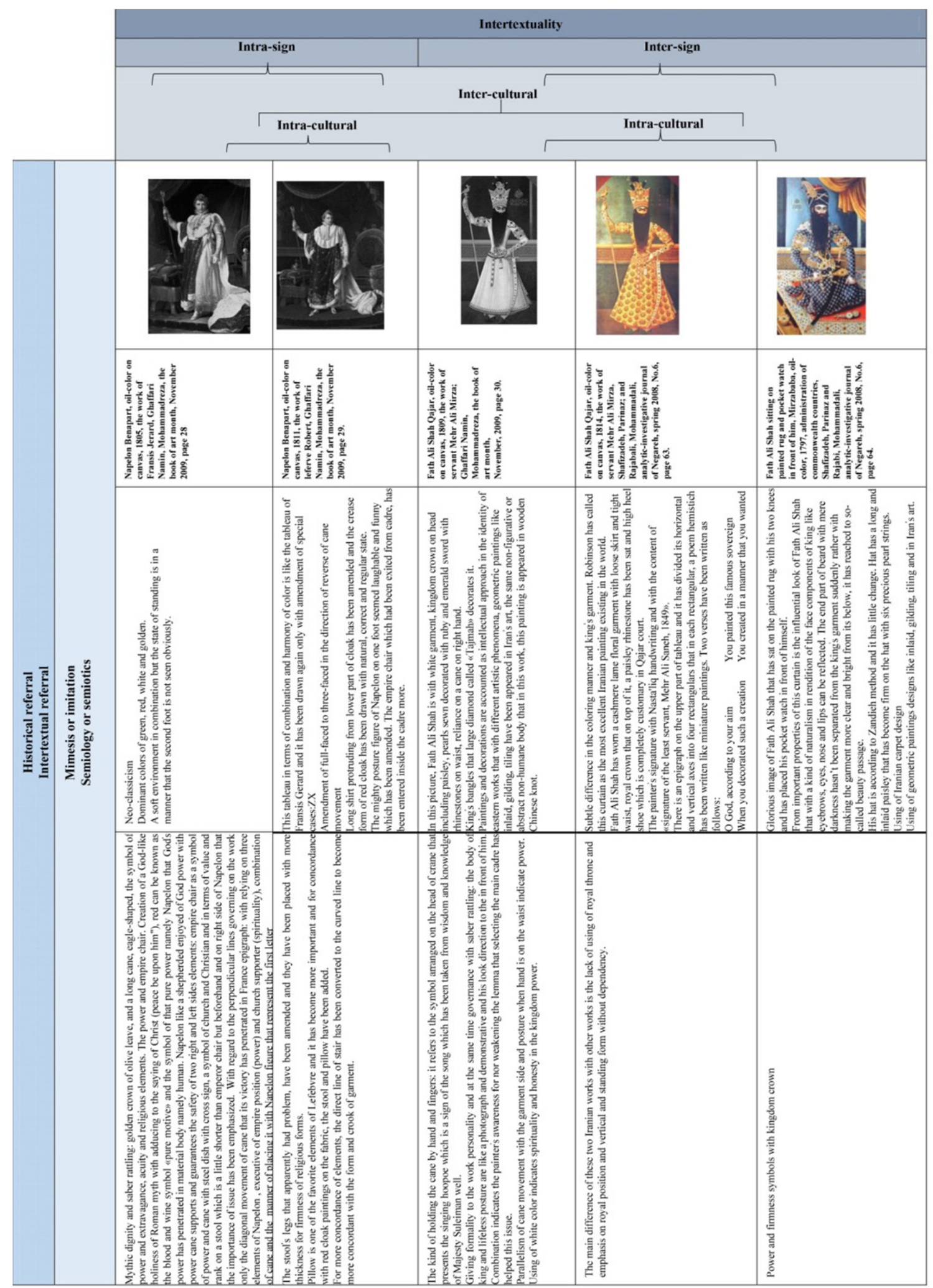


Table 5. Studying the paintings of the first period of Qajar according to intertextuality (reference: authors)

\begin{tabular}{|c|c|c|c|c|}
\hline & & \multicolumn{3}{|c|}{ Intertextuality } \\
\hline & & \multicolumn{3}{|c|}{$\begin{array}{l}\text { Inter-sign } \\
\text { e the explanation of daily events has been expressed through } \\
\text { tem instead of writing text. }\end{array}$} \\
\hline & & \multicolumn{3}{|c|}{ Intra-cultural } \\
\hline 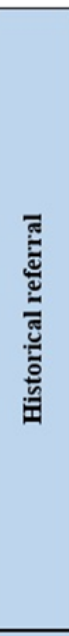 & 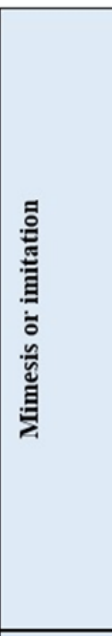 & $\begin{array}{l}\text { The paintings of Mahmoudkhan indicate that he } \\
\text { is familiar with western painting and look. He } \\
\text { doesn't use of mere imitation in his works and } \\
\text { he causes all things to pass from the filter of his } \\
\text { artistic view and Iranian root. } \\
\text { Water-color image of Almasieh street landscape } \\
\text { in which different persons are coming, going } \\
\text { and trading. } \\
\text { In this tableau, a precision has been applied in } \\
\text { drawing the foliage of trees and it reminds the } \\
\text { elegance and elaborate work of author in his } \\
\text { artistic works. } \\
\text { A painting-like order in drawing the chambers } \\
\text { and false arches of both sides of street, tiling } \\
\text { and the persons inside the street that have } \\
\text { elegance and order. } \\
\text { The trees landscape and Almasieh façade at the } \\
\text { end of street have been painted with special skill } \\
\text { and this work has signature: "servant of } \\
\text { Mahmoud's court, 1909». }\end{array}$ & $\begin{array}{l}\text { Landscape of } \\
\text { Almasieh } \\
\text { façade (imperial } \\
\text { door), } \\
\text { Mahmoudkhan, } \\
\text { Malekolshoara, } \\
\text { water-color, } \\
\text { Golestan palace } \\
\text { museum, 1909, } \\
\text { Shafizadeh, } \\
\text { Parinaz; Rajabi, } \\
\text { Mohammadali, } \\
\text { analytic- } \\
\text { investigative } \\
\text { journal of } \\
\text { Negareh, spring } \\
\text { 2008, No.6, } \\
\text { page 67. }\end{array}$ & 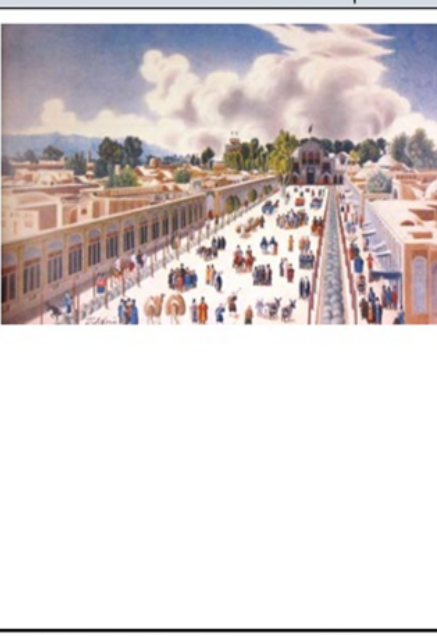 \\
\hline 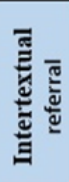 & 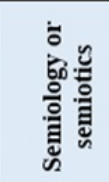 & \multicolumn{3}{|c|}{$\begin{array}{l}\text { In this work, artist expresses a kind of daily routine and it has been drawn following from imagery of Europe } \\
\text { streets especially Paris streets. }\end{array}$} \\
\hline
\end{tabular}

Table 6. Studying the paintings of the second period of Qajar according to intertextuality (reference: authors)

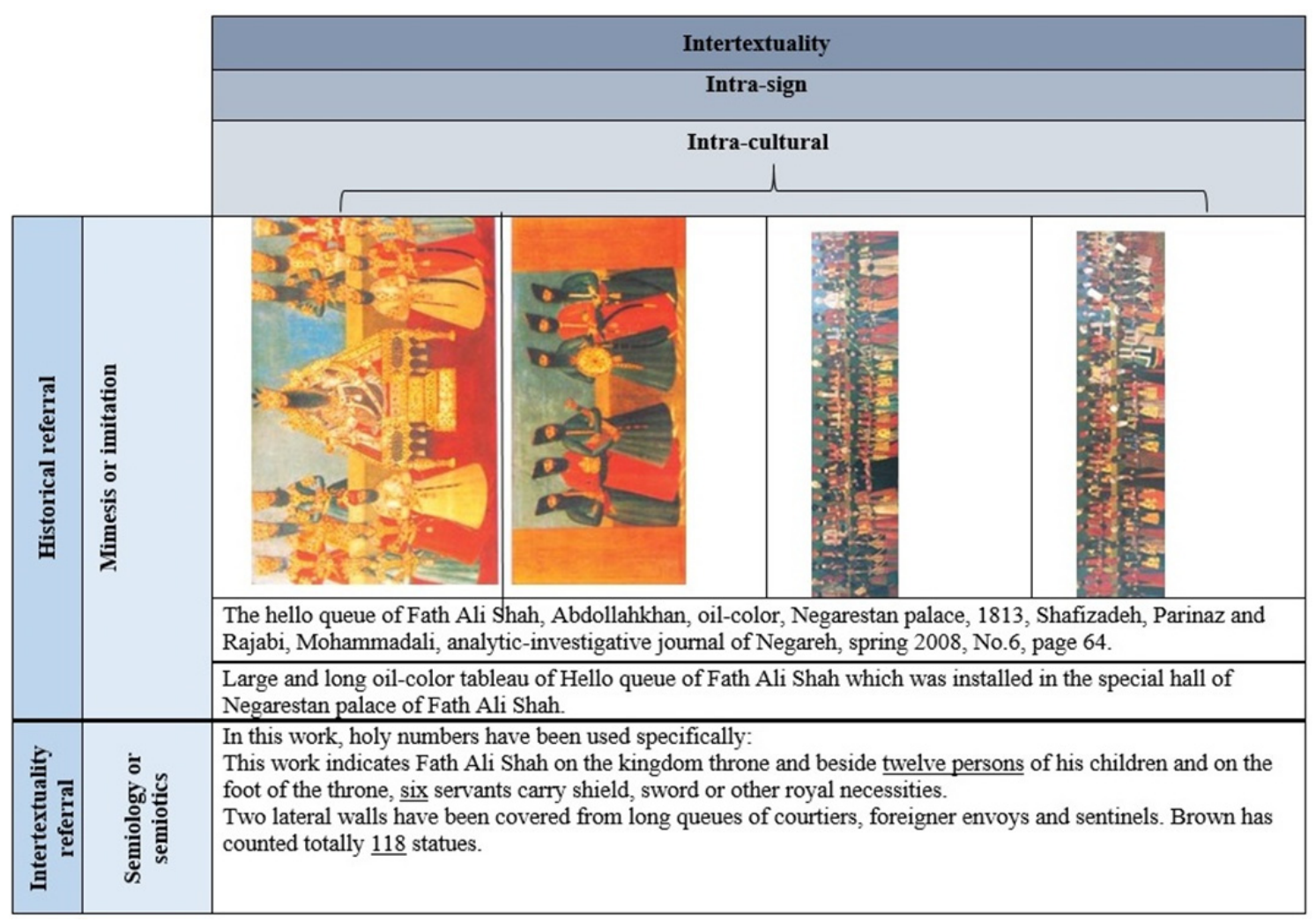


Table 7. Studying the paintings of the third period of Qajar according to intertextuality (reference: authors)

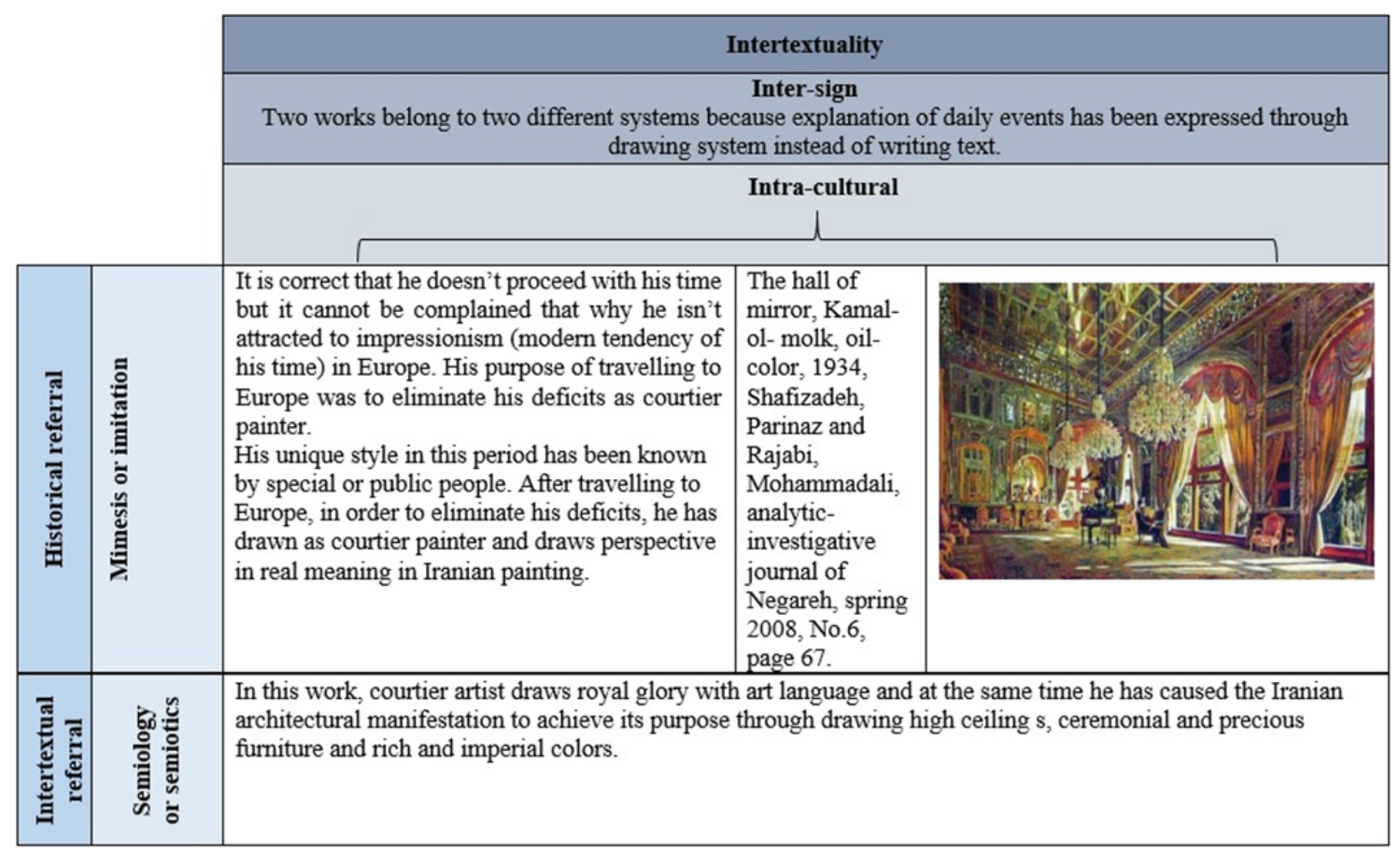

\section{Conclusion}

In this article, we studied the existence of signs world in intertextuality and its effects on creation of painting works existing from Qajar era. The world has been combined from cultural signs and texts and a network called intertextuality links these texts to each other. According to the existing study, we saw that the range and effects of the signs world have been considered in the creation of cultural works of Qajar to what extent. Intertextuality brings semantic plurality and significance with itself and due to it, the discussed texts changed their nature to multi-meaning and multi-layer texts (according to the related tables).

Intertextuality is a method which considers the reading of a text or artistic work aligned with other texts and with this method, it considers an effect that previous texts have on creation of new works. Each artistic work with keeping the contemporary space of the creator of the work keeps the previous maximum effect on itself and represents it. In this research, the adherence and interaction between the previous and next texts were pursued merely in one of the periods of Iran's art history and due to the vastness of issue we have sufficed merely to introduce few samples that undoubtedly can be generalized in all periods of art history and this issue demands special reflection. Also according to the researches of previous researchers, this research also expresses this point that non-local methods can be utilized for studying in each region and in the event of necessity, we localize them.

With regard to the studies of art history in this period, for reading the painting works totally a structure like the following case can be referred that of course this is accounted only one kind of reading of a reader:

The kind of reading the painting in intertextuality

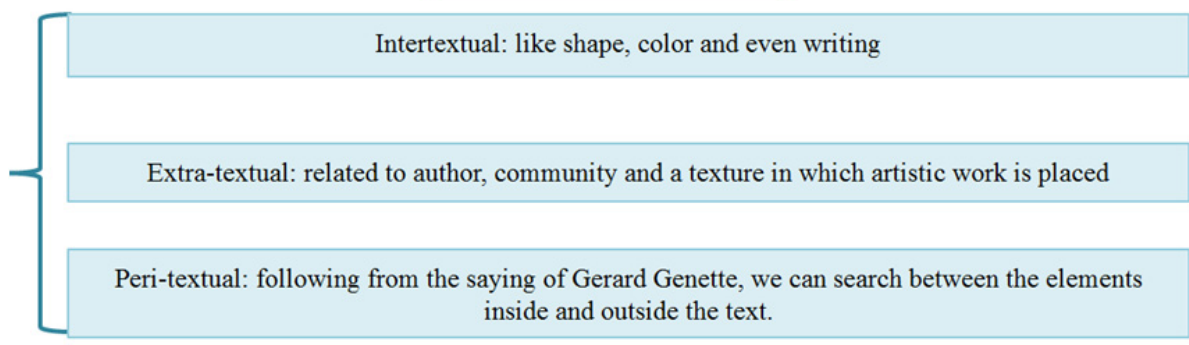




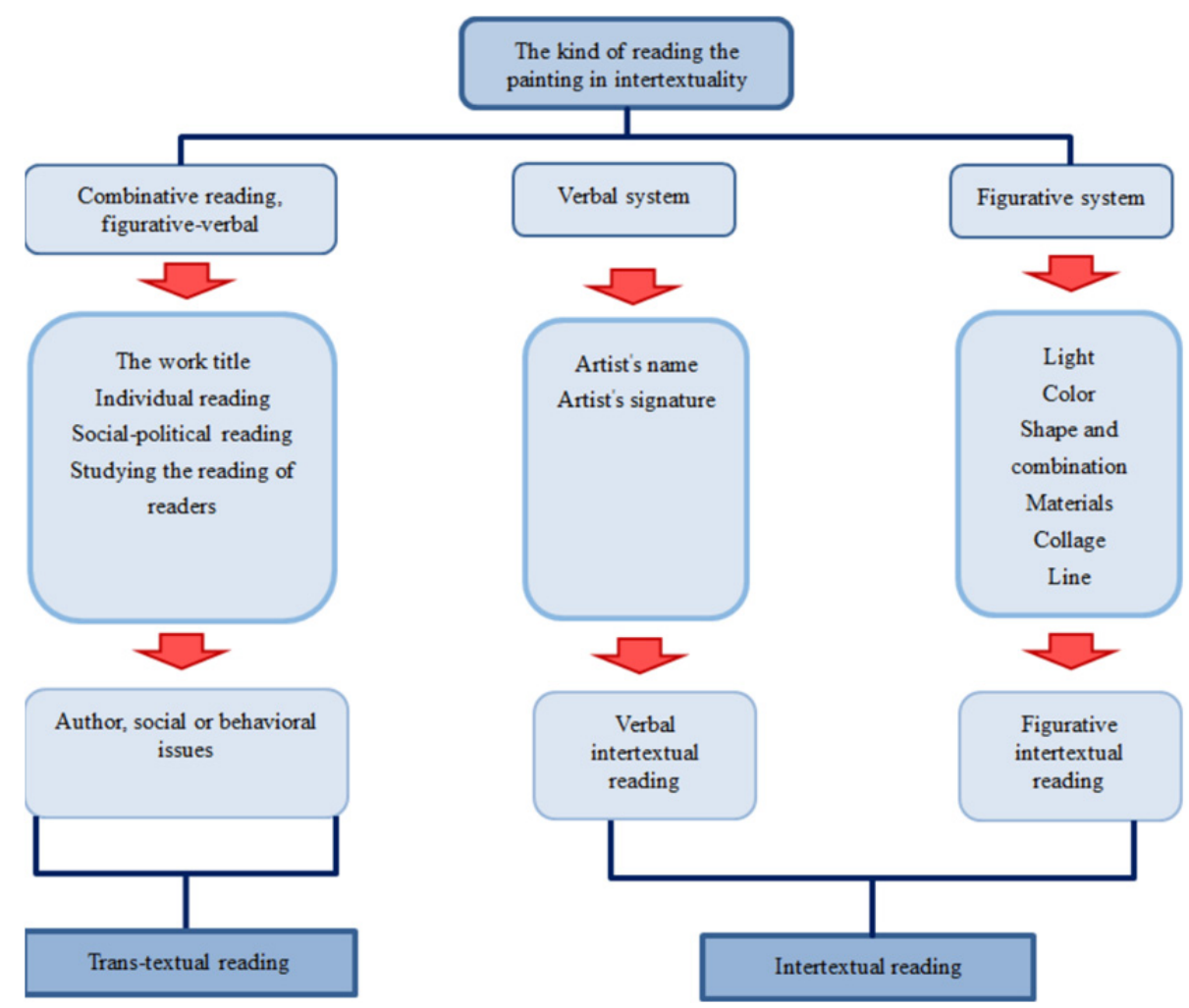

Figure 2. Diagram of reading the painting in intertextuality (reference: authors)

\section{References}

Allen, G. (2006). Intertextuality (Yazdanjou, Payam, \& Tehran, Trans.).

Abrams, M. H. (2005). Descriptive lexicon of literal terms (9th Ed.) (Sabzian, S., \& Tehran, R., Trans.), 2008.

Barthes, R. (2003). Text pleasure (Yazdanjou, Payam, \& Tehran, Trans.).

Hosseini, M. (2003). Modernism foundations in Iran's painting. Specialized Journal of Art University, 6(20).

Shafizadeh, P., \& Rajabi, M. (2008). Courtier (formal) paintings of Qajar, demonstration of image glory. Negareh, (6).

Ghaffari, N. M. (2009). The book of art month, November.

Ghaeminia, A. (2010). Text biology: Semiology and interpretation of Koran. Tehran: Research-institute of Islamic culture and thought.

Namvar Motlagh, B. (2007). A reflection on intertextuality theory of Roland Barthes. Iran newspaper, (3760).

Namvar Motlagh, B. (2011). A prelude on intertextuality: Theories and applications (No.1 from the set of literal and artistic theories and criticisms). Tehran, Sokhan.

\section{Copyrights}

Copyright for this article is retained by the author(s), with first publication rights granted to the journal.

This is an open-access article distributed under the terms and conditions of the Creative Commons Attribution license (http://creativecommons.org/licenses/by/4.0/). 